Original Article

\title{
Being the mother of a pregnant adolescent: experiences and expectations*
}

\author{
Ser mãe de adolescente grávida: vivência e expectativas \\ Ser madre de adolescente embarazada: vivencia y expectativas
Sebastião Caldeira ${ }^{1}$, Miriam Aparecida Barbosa Merighi ${ }^{2}$, Maria Cristina Pinto de Jesus $^{3}$, Deíse Moura de Oliveira ${ }^{4}$, Selisvane Ribeiro da Fonseca Domingos ${ }^{5}$, Roselane Gonçalves ${ }^{6}$

\begin{abstract}
Objective: To understand the typical actions of the mother during the pregnancy of her teenage daughter. Methods: Qualitative study, based on the theoretical-methodological framework of social phenomenology of Alfred Schütz. The data were collected in 2009, and the subjects were nine mothers of adolescent primigravidae. Results: The mother of the pregnant adolescent is typified as one that reacts with surprise and disappointment to being notified of the pregnancy and who, subsequently, conforms to the new reality. In reflecting on her own experience of an adolescent mother, she has expectations to support her daughter during the pregnancy and to offer support, so that the course of her life is not impaired as a result of pregnancy. Conclusion: Considering the experience and expectations of the mother of the pregnant adolescent, this study could give subsidies to the planning and execution of the care for this binomial, decreasing the distance between the demands made by it and the practice of health professionals.
\end{abstract}

Keywords: Pregnancy in adolescence; Family relations; Qualitative research

\section{RESUMO}

Objetivo: Compreender o típico da ação da mãe diante da gravidez da filha adolescente. Métodos: Pesquisa de abordagem qualitativa, fundamentada no referencial teórico-metodológico da fenomenologia social de Alfred Schütz. Os dados foram coletados, em 2009, e os sujeitos foram nove mães de adolescentes primigestas. Resultados: A mãe de adolescente grávida é tipificada como aquela que reage com surpresa e decepção à notícia da gravidez e que, posteriormente, se conforma com a nova realidade. Ao refletir sobre sua própria experiência de mãe na adolescência, tem expectativas de apoiar a filha na gestação e oferecer-lhe suporte, para que o curso de sua vida não seja prejudicado em decorrência da gravidez. Conclusão: Considerando a vivência e as expectativas da mãe de adolescente grávida, este estudo pôde conferir subsídios ao planejamento e efetivação do cuidado a esse binômio, diminuindo a distância entre as demandas por ele apresentadas e a prática dos profissionais de saúde. Descritores: Gravidez na adolescência; Relações familiares; Pesquisa qualitativa

\section{RESUMEN}

Objetivo: Comprender la típica actitud de la madre frente al embarazo de su hija adolescente. Métodos: Investigación de abordaje cualitativo, fundamentada en el referencial teórico-metodológico de la fenomenología social de Alfred Schütz. Los datos fueron recolectados, en el 2009, y los sujetos fueron nueve madres de adolescentes primigestas. Resultados: La madre de adolescente embarazada es tipificada como aquella que reacciona con sorpresa y decepción frente a la noticia del embarazo y que, posteriormente, se conforma con la nueva realidad. Al reflexionar sobre su propia experiencia de madre en la adolescencia, tiene expectativas de apoyar a su hija en la gestación y ofrecerle soporte, para que el curso de su vida no se perjudique como consecuencia de su embarazo. Conclusión: Considerando la vivencia y las expectativas de la madre de adolescente embarazada, este estudio puede conferir subsidios a la planificación y efectividad del cuidado a ese binomio, disminuyendo así la distancia entre las demandas presentadas y la práctica de los profesionales de salud.

Descriptores: Embarazo en adolescencia; Relaciones familiares; Investigación cualitativa

\footnotetext{
* Study from the Research Group in Nursing with phenomenological approaches. School of Nursing, University of São Paulo-USP - São Paulo (SP), Brazil.

${ }^{1}$ PhD in Sciences. Adjunct Professor, State University of Western Paraná, Cascavel (PR), Brazil.

${ }^{2}$ PhD in Nursing. Full Professor, School of Nursing, University of São Paulo-USP - São Paulo (SP), Brazil.

${ }^{3} \mathrm{PhD}$ in Nursing. Associate Professor, Federal University of Juiz de Fora (MG), Brazil.

${ }^{4}$ PhD student in Science. School of Nursing, University of São Paulo-USP - São Paulo (SP), Brazill.

${ }^{5}$ PhD in Sciences. School of Nursing, University of São Paulo-USP - São Paulo (SP), Brazil.

${ }^{6}$ PhD in Nursing. Professor, School of Arts, Sciences and Humanities, University of São Paulo-USP - São Paulo (SP), Brazil.
} 


\section{INTRODUCTION}

Teenage pregnancy is a complex phenomenon, which associated with various economic, educational and behavioral factors, problems emerge due to early $\operatorname{motherhood}^{(1)}$.

In this regard, these problems are losses that may affect the emotional field and lead to the adolescent psychological somatization, with signs and symptoms that could compromise a healthy pregnancy ${ }^{(2)}$.

In this context, the pregnancy risks are related, among others, to psychological aspects and lack of family support, factors that may lead to high levels of stress and psychological distress ${ }^{(3)}$. The complexity of this situation contributes to, often, so that the teen pregnancy becomes a stressful event in nature, with potential changes in family dynamics ${ }^{(4)}$.

The impact of these changes and their characteristics depend on the beliefs and values prevailing in each family. Thus, pregnancy is not always seen as a negative fact essentially, therefore often family binds to minimize the undesirable consequences of the event and make it positive for both themselves as for the young parents ${ }^{(5)}$.

In some families, the teen pregnancy may be considered a natural and desired event, especially when there is a stable union between the teenager and the father of the child ${ }^{(6)}$; in other families, this event may come permeated with violence by parents of the pregnant young woman ${ }^{(7)}$. A study on domestic violence against pregnant teenagers showed that the revelation of pregnancy led to conflicts and violence that manifested both in physical form - beating - and even as in a psychological form, inducting an abortion ${ }^{(7)}$.

The family, especially the mother, may represent a fundamental support, since this is usually the most important figure of identification with the teenager, among the women of the family. The adolescent network of significance, with respect to these women, consists in the following order: mother, maternal grandmother, paternal grandmother, sisters and aunts. Besides the possibility of a greater tendency to repeat features from mother to daughter, women value being able to take care of themselves, both in the personal and the professional aspects, in order to favor the autonomy of the young girl who is becoming a woman ${ }^{(8)}$.

The mother-daughter relationship is fraught with meaning. From this perspective, a study showed that teenagers have a positive perception of one's own mother - the mother is perceived as present figure in the adolescent life, she helps her to know her roles and femininity, becoming a mediator between daughter and external events ${ }^{(8)}$.

Given the above, this research was based on the following concerns: how did mothers experience the con- dition of having a pregnant teenage daughter? What are their expectations about this experience? The objective of this study was to understand the typical action of the mother given the pregnancy of her teenage daughter.

The results of this research will contribute to the debate about what is experienced by mothers of pregnant adolescents and provide insights to the actions of health care to consider the context of adolescent experiences that involve the family, especially mothers.

\section{METHODS}

This is a qualitative study, based on the theoretical-methodological social phenomenology of Alfred Schütz, with anchor on the following concepts: social world, intersubjectivity, mutual prospects, biographic situation, background knowledge, motivation, social action and typification.

In this research, we included women who, at the time of data collection, experienced the first pregnancy of their teenage daughter. They should also be enrolled in the study setting - a unit of primary health care in a municipality d'Oeste in the State of Parana, being disregarded those who did not meet the established criteria.

The contact with the participants took place on the basis of survey data available in the records of the Information System of Primary Care study setting. The search and contact with mothers of pregnant adolescents were mediated by the Community Health Agent from the microarea to where they belonged.

The study was conducted with nine mothers of pregnant adolescents. Statements were obtained between October and December 2009, through a recorded interview that contained the following opened questions: tell me about your experience of having a pregnant teenage daughter and what are your expectations faced with this situation?

The interviews were conducted on days and times set by mothers in their homes - private environment that enabled them to talk freely about the research questions. Data collection was finished when the statements became repetitive, and the speeches content answered concerns to the purpose of the study.

Mothers who agreed to participate were given all the information about the study and signed a Consent Form. To ensure anonymity, participants were identified with the word Mother, followed by Arabic numerals from 1 to 9.

The result analysis was conducted as the steps proposed by the social phenomenology ${ }^{(9)}$ : careful reading and rereading of each statement to grasp the global meaning of the experience of the mother going through the experience of having a pregnant teenage daughter; identification and subsequent grouping of significant 
aspects of the statements to the composition of concrete categories - objective summaries of the different meanings of emerged action from lived experiences; analysis of these categories, seeking to understand the "reasons for" and "reasons why" the action of these mothers, discussion of results in light of social phenomenology of Alfred Schütz and studies related to the topic.

This study was submitted to the Ethics Research Committee of the State University d'Oeste do Parana - CEP-UNIOESTE with Approval No. 399/2009.

\section{RESULTS}

Although it has not been constituted as an inclusion criteria for the study, all participants were also pregnant teenagers. Most were married, were aged between 32 and 47 years and had uncompleted primary education.

Aiming to understand the typical action of the mother given the pregnancy of her teenage daughter, it was decided that the context of meanings derived from this experience understand the impact of the pregnancy news to the launched expectations based on that event, culminating respectively in categories: reaction to pregnancy and support offered to daughter.

\section{Reaction to pregnancy}

Faced with the news of her daughter's teenage pregnancy, the mother external to reactions against an unexpected reality. Once that the fact is already done, so she outlines conformism, after the impact of the news:

"When we found out [...] it was a shock, a surprise, we weren 't expecting for that" (Mother 2).

"It was a disappointment, they are both very young. [...] We can not do anything, it's already done. [...] We were frightened" (Mother 4).

"At first, I was really nervous because I did not know what would be her future with this man" (Mother 8).

As the mother faces her daughter's pregnancy, she refers to her past as a teenage mother and reacts to prevent her daughter to go through the difficult experiences she went through:

"[... I went through a teenage pregnancy, it was terrible and I do not want that for her [... " (Mother 1).

"[...] We've been through this [...], I was mother when I was 18 years old [...]I was also not old enough, but, for her, being 13 years old, it's even worse; I believe she will need more support" (Mother 2).

"[...] I was pregnant with her when I was 14 years old (pregnant daughter) [...] I went through very bad things. My mother knew but did not accept [...]. She hasn't been through what I did and I don't want her to go through what I did when I was pregnant with her" (Mother 3).

Reflecting on her own experience of teenage pregnancy, the mother sets out to prevent her daughter to experience difficult situations through which she did. For this purpose, she offers support and care to her daughter and throw expectations that involve the responsibility to take care of themselves and the unborn child. Such designs express the "reasons for" represented by category: support offered to daughter.

\section{Support offered to daughter}

Wishing her daughter live in a more peaceful and secure experience of teenage pregnancy, the mother is willing to support her and meet the needs of care required at this point in the life cycle:

"[...] The thing is to accept, support, there is no use putting her out of the bouse" (Mother 1).

"[... Now, we have to support and see which is the best way for this child to be born well" (Mother 2).

"[...] I have to help, I cannot leave her [...]" (Mother 7).

The support given by mother to daughter aims to offer subsidies, so that she can lead her life responsibly with regard to caring for her child and herself:

"[... I want this child and that she (the daughter) grows at least a little [...] she is not prepared for pregnancy [...] I have to look after and guide her" (Mother 1).

"She will learn to care for her child with our support [...] I want to help and be with her at the beginning [...] then she has to do it herself" (Mother 5).

Given the expectation that her daughter live motherhood responsibly, the mother expects, at the same time, that the adolescent may gradually resume her normal life. Thus, expressed a desire to continue her studies, involving the future of her daughter:

"I talk to her (the danghter) it is not because of a child you have to stop your life. I want her to have a chance to finish it (her studies) because she has a whole future abead "(Mother 3).

"[...] Continue her studies and go to college! That's all I want for her" (Mother 6).

"I want her to devote herself to her baby [... I do not know if she will continue to study, she wanted to go to college [...] I hope that pregnancy does not jeopardize her" (Mother of 9).

\section{DISCUSSION}

Adolescence is a period when pregnancy is reflected as an early event. From the perspective of the mother of a teenager, this fact is characterized as an unexpected event and, at first, leads to reactions of surprise and discontent; later acceptance.

A study of early pregnancy indicates that families of pregnant adolescents have different reactions when they learn about the pregnancy; these involve feelings that lead to denial, anger and worry. However, after the impact of the news, these feelings give way to reception and joy. In this context, it is the mother who, most often, more openly accepts her daughter's pregnancy ${ }^{(4)}$. 
The relationship between mother and teenage pregnant daughter occurs in the world of life, also called social world. This is a scenario in which humans coexist and live together, understanding and being understood through intersubjective relations that are established ${ }^{(10)}$.

The intersubjectivity that emerges in the mother-daughter relationship underpins the other states in this social world. The fact that the mother is the one who best welcome her daughter's pregnancy, goes through the identity construction of women as one who cares and experience mothering. This allows the mother, seeing her daughter experiencing this process, to better understand it outside her own experience of being a mother. The situation becomes even more identifying with the experience of her daughter when she herself experienced teenage pregnancy, which proved to be typical in the statements of this research.

Study on the family trajectories and conceptions of family of women who were teenage mothers showed that their mothers also experienced teen pregnancy ${ }^{(4)}$. Family history is considered a relevant factor. Commonly, the young woman who becomes pregnant is often the daughter of mothers who became pregnant as teenagers, such an event may be recurrent in other family members ${ }^{(2)}$.

It is considered therefore that the mother turns intentionally for the state of her daughter's pregnancy, and seeking to understand it based on her own experience. This relationship assumes reciprocity between the two intentions. The concept of reciprocity of perspectives refers to how knowledge is apprehended. Reciprocal prospects are typical objects of thought constructions that translate the apprehension of these, aspects of which are known to all ${ }^{(10)}$. In the case of this study, the aspects related to teenage pregnancy are known by mother and daughter through reciprocal perspectives that make them cohabit the same situation.

Common sense is the matrix of all social action, and each person lies in a specific way in this world biographical situation. However, each person receives information of their predecessors, plus the daily experiences, knowledge complement their background. This constitutes a subsidy to the comprehension of the world, boosting the subject for social action ${ }^{(10)}$.

The action of the mother given her daughter's pregnancy is punctuated by biographical situation in which it is and the background knowledge acquired throughout life. Here we must consider, in particular, her experience of being an adolescent mother, as an event that propels projects to glimpse at her daughter who experiences the same situation.

It was evident that the mother has the expectation to support her daughter meet the needs of care provided for her during and after pregnancy. The family support the teenager was exemplified in a study showing that the accommodation of her and her child at home when she is still single. Moreover, such support was evident in the form of financial aid or assistance in parenting ${ }^{(5)}$.

A study on teenage pregnancy, from the perspective of the family, showed changes in relationships and practices among family members and pregnant teens. Family concern with physical well-being of youth and offering subsidies for care during pregnancy and after child birth is highlighted ${ }^{(6)}$.

In the case of the mother, her originating role of caring permeates the established relationships in the world of life. The idea that women are essentially caregivers, have their origin in the apparent indissociation female body with motherhood, which is considered an essentially natural relationship the existence of being women $^{(11)}$. This aspect is heavily discussed in studies of gender perspective.

The existential motivation leads the mother to care for her teenage daughter. This motivation leads subjects to action that is imagined and comes from the background knowledge and biographical situation of each subject ${ }^{(10)}$. The mother, based on the experiences of caring for a pregnant teenage daughter, sees continuously restructured actions, based on different situations that will subsidize other motivations and lead to new actions of caring.

The action is defined as a human conduct designed by the subject, of awareness mode, which is never isolated and detached from another action ${ }^{(10)}$. Therefore, from the moment the mother designs the initial support to her pregnant daughter, consciously and intentionally, also designs care actions that transcend pregnancy, including the needs that permeate her daughter's life hereafter.

In adolescence, the situation of pregnancy interrupts projects, drives the adolescent and their families to rebuild their life plans and reflect on their experiences ${ }^{(6)}$. In contrast, discontinuation of some projects gives rise to the development of new projects, thus opening possibilities for the life of the pregnant teenager and her family.

Among these projects, those for after the pregnancy related to the adolescent life and care for her child emerge. One study showed that family members have expectations for the roles to be played by the pregnant teenager, when it comes to their social behavior and their preparedness to take responsibility for the child who will be born ${ }^{(6)}$.

Their studies continuation also represents projects that mothers envision to their pregnant teen daughters. In adolescence, pregnancy may lead to interruption of studies, but it does not exclude a return to school to meet the new demands of motherhood ${ }^{(12)}$. Therefore, we should also consider the concern of mothers with their daughter`s future, they will be forced to assume new responsibilities, social so they can care for their child. 
Although pregnancy causes a structural change in the lives of teenagers and their families, it also features an experience that gives maturity, greater responsibility and personal satisfaction to the young mothers ${ }^{(13)}$.

The set of categories allowed the construction of the typical action - the typification - which refers to a type of personal lives in a real social world and performing a typical act. The ideal type of person who is never identical to a particular person or a certain group of people, provides an understanding of man in his social relations ${ }^{(10)}$.

Thus, the mother of the teenage pregnant is a typification as one that reacts with surprise and disappointment to the news of the daughter's pregnancy, but who subsequently resigned to the new reality. Reflecting on her own experience of an adolescent mother, who has expectations of support during pregnancy and child support, so that the course of her life is not impaired as a result of pregnancy.

Given the typical enrolled in the group of mothers of teenage pregnancy, we have to think that learning about the experiences of families faced with teenage pregnancy may be essential to allow the line between care provided by health professionals and the needs of adolescents and their families ${ }^{(14)}$. In this regard, the practice of nursing must take into account the expectations, relationships and family contexts to support the care of adolescents and their families ${ }^{(6)}$.

\section{REFERENCES}

1. Chalem E, Mitsuhiro SS, Ferri CP, Barros MC, Guinsburg $\mathrm{R}$, Laranjeira R. Teenage pregnancy: behavioral and sociodemographic profi le of an urban Brazilian population. Cad Saúde Pública. 2007; 23(1):177-86.

2. Moreira TMM, Viana DS, Queiroz MVO, Jorge MSB. [Conflicts experienced by female adolescents with the discovery of pregnancy]. Rev Esc Enferm USP. 2008; 42(2): 312-20. Portuguese.

3. Correia DS, Santos LV, Calheiros AM, Vieira MJ. Adolescentes grávidas: sinais, sintomas, intercorrências e presença de estresse. Rev Gaúcha Enferm. 2011; 32(1):40-7.

4. Matta JS. E a família, como vai? Trajetórias familiares e concepções de família em mulheres que foram mães na adolescência: o caso do Centro de Saúde Germano Sinval Faria [tese]. Rio de Janeiro: Escola Nacional de Saúde Pública Sérgio Arouca; 2008.

5. Hoga LAK, Borges ALV, Reberte LM. [Reasons and consequences of adolescent pregnancy: testimonies of family members]. Esc Anna Nery Rev Enferm. 2010; 14 (1):151-7. Portuguese.

6. Silva L, Tonete VL. A gravidez na adolescência sob a perspectiva dos familiares: compartilhando projetos de vida e cuidado. Rev Latinoam Enferm. 2006; 14(2):199-206.

\section{FINAL CONSIDERATIONS}

The typical understanding of the mother action with regard to her teenage daughter's pregnancy evokes the existence of a relationship strongly marked by reciprocity of intentions and by matching the experience of mothering. In this sense, the mother welcomes her pregnant daughter and offers emotional and affective support, so she can experience pregnancy and motherhood with greater ease and safety.

In literature, there are studies that consider the interface of teenage pregnancy with her family dimension, but there is a gap when it comes to research on the experience of the mother of her teenage daughter pregnancy.

Considering the specific aspects emanating from the mother-daughter relationship, explained in this study, it is suggested that further investigations may look into this perspective, revealing aspects not yet covered.

The subject's typical characteristic of being also teenage mothers, although it reflects a particularity of this study, show limitations, because the results represent a particular social group, inserted in a specific scenario.

This study is important, considering the experience and expectations of mother to her teenage daughter pregnancy, it has given contributions for the planning and execution of care to be allocated to this binomial, decreasing the distance between the demands presented by them and the practice of health professionals.

7. Monteiro CF, Costa NS, Nascimento PS, Aguiar YA. [Intrafamiliar violence against pregnant adolescents] . Rev Bras Enferm. 2007; 60(4):373-6. Portuguese.

8. Seron C, Milan RG. A construção da identidade feminina na adolescência: um enfoque na relação mãe e filha. Psicol Teor Prat. 2011; 13(1):154-64.

9. Jesus MC. A educação sexual na vida de pais e adolescentes: uma abordagem compreensiva da ação social [tese]. São Paulo: Universidade de São Paulo, Escola de Enfermagem da; 1998.

10. Schutz A. Estudios sobre teoria social: escrito II. Buenos Aires: Amorrortu; 2003.

11. Almeida L. As mães e as filhas e as avós e as netas nas narrativas genealógicas. Destiempos. 2009; 4(19):605-28.

12. Oliveira RC. [Adolescence, pregnancy, and maternity: selfperception and the relationship with work] . Saúde Soc. 2008. 17(4):93-102. Portuguese.

13. Carvalho GM, Merighi MA, Jesus MC. The experience of repeated fatherhood during adolescence. Midwifery. 2010. 26(4):469-74.

14. Hoga LA, Borges AL, Alvarez RE. Teen pregnancy: values and reactions of family members. Acta Paul Enferm. 2009; 22(6):779-85. 